\title{
Soil formation in Late Glacial Meuse sediments related to the Peel Boundary Fault activity
}

\section{R. Miedema* \& T. Jongmans}

Wageningen University, Laboratory for Soil Science and Geology, P.O.Box 37, 6700 AA Wageningen, The Netherlands; e-mail: rienk.miedema@, alg.osa.wau.nl * corresponding author

Manuscript received: July 2001; accepted: October 2001

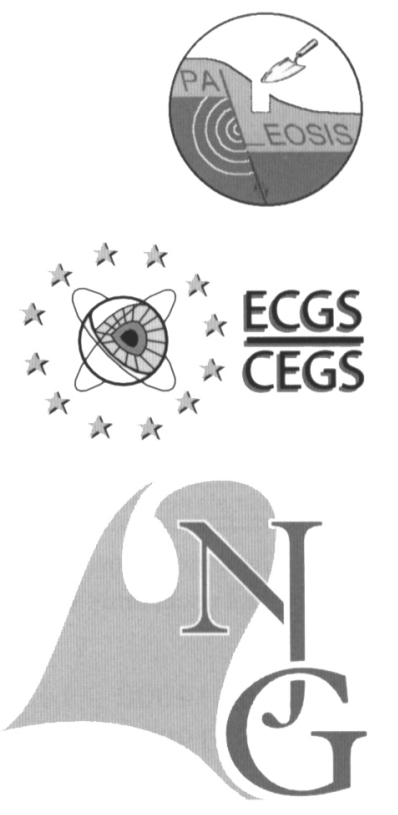

\begin{abstract}
Micromorphological studies relating the soil formation history (processes and timing) to activity events of the Peel Boundary Fault (PBF) showed rotation features (circular distribution pattern of sand grains) in mechanically displaced rounded fragments of Bt bands. These features are interpreted as being caused by 'mudflow' during active faulting event (PBF event F2). The micromorphological interpretation of Late Weichselian soil formation (clay illuviation, degradation features and offsetting of Bt bands) agrees with the hypothesized 3 PBF periods of fault activity events (F1, F2 and F3).
\end{abstract}

Key words: soil formation, (banded) Bt horizon, micromorphology, clay illuviation, ferrolysis, rotation features, active faulting

\section{Introduction}

Field studies in a trench across the Peel boundary fault (PBF) near Neer (Van den Berg and Lokhorst, 1999) reveal that the macromorphology of the geogenic layers and pedogenic horizons, developed in such layers, was influenced distinctly by activity events of the PBF. These authors distinguished three phases of fault activity in the trench (F1-F3). All three phases are younger than the Beuningen gravel bed of about 16000 yrs BP, because the Beuningen gravel bed has been offset. In their reconstruction also Meuse terrace levels due to climatic forcing are used (Kasse et al., 1995; Van den Berg, 1996; Tebbens et al., 1999). Their results make a comparison possible with the sequence of events in time based on the interpretation of the various pedological processes.

The aim of this investigation was to relate the soil formation history (processes and timing) to activity events of the PBF. We studied thin sections using a petrographic microscope.

\section{Material and methods}

In the cross section of the trench near Neer the parent material consists of Late Weichselian sandy colluvial material, overlying in situ fluvio-aeolian sandy deposits with the Beuningen gravel bed. It shows an overview of the geogenic parent materials with bedding characteristics, frost cracks and faults, pedogenic layers and biological activity of dung beetles.

Ten undisturbed micromorphological samples ( $7 \times 7$ $\mathrm{cm}$ ) were taken at micro-sites where these activity phases have taken place (Fig. 1). For each subset of those samples specific questions regarding the interaction between soil formation and geological setting in time were phrased:

F1 event: 15000 - 15500 yrs BP (Van den Berg and Lokhorst, 1999):

Sample sma 6 is taken where macromorphologically nearly vertical pedogenically influenced layers are observed in the offset. Questions relate to the sequence of soil formation and fault activity. 


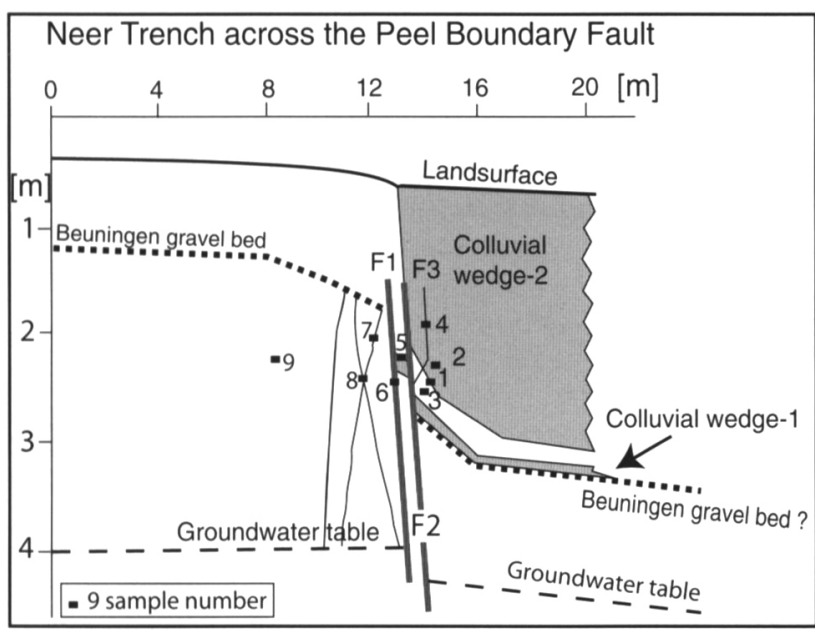

Fig. 1. Geological cross section of trench with sampling sites of micromorphological samples (after M. van den Berg).

F2 event: 14000 - 14200 yrs BP (Van den Berg and Lokhorst, 1999).

The samples sma 1,2 and 5 are taken where macromorphologically Late Weichselian colluvium overlies in-situ deposits. Questions focus on the infilling of the fault, whether the fault continues into the overlying Late Weichselian colluvial deposits and the characteristics of the soil formation in the infilling and surrounding the fault.

F3 event: Holocene (Van den Berg and Lokhorst, 1999):

The F3 is situated within the F2 fault trace in the Late Weichselian colluvial deposits.

Samples sma $4 a / b$ (vertical and horizontal sample) are taken where macromorphologically a faulttrace containing organic matter is observed. The questions are about the nature of the organic matter and the soil formation in and surrounding the infilling.

\section{Additional samples without clear reference to F1-F3:}

Samples sma 7 and 8 are located north of and close to the $F 1$ fault (where the Beuningen gravel bed is not yet offset, but occurs in a tilted position) and sample sma 9 is taken further north from the F1 offset. These samples are associated with bleached, fissure-like structures showing only minor to no displacement . How does the structure and composition of the bleached infilling compare to the surrounding $\mathrm{Bt}$ horizon and how and when has it formed (roothole/ relaxation fissure?).

The samples were airdried and impregnated under vacuum with Synolite resin diluted with acetone (FitzPatrick, 1970), and cut and ground to $30 \mu \mathrm{m}$ thin sections. They are described using the terminology of Bullock et al. (1985).

\section{Optical observations and interpretation}

We will discuss the thin sections in the sequence from F1 to F3. Firstly observations and interpretations from the individual thin sections will be reported. The overall interpretation of all thin sections will be presented in the section 'discussion and synthesis'.

F1: Sample sma 6 is taken in a part with clear sedimentary stratification, oriented almost vertical to the soil surface. Optical observations in the reddish brown parts of this changed layered deposit demonstrated the presence of many in-situ translucent, orange-yellow, strongly oriented, fine textured free grain and vugh coatings, forming a bridged grain microstructure (Fig. 2). These are the result of clay translocation processes. Clay translocation may already occur in a full cold period without vegetation (Beuningen) but the translocated clay is taken up in the groundmass by mechanical stresses (frost, frost heave -Van Vliet-Lanoë, 1988) . Therefore we conclude that the activity event $F 1$ has changed the horizontal geogenic strafication of the deposits into nearly vertical, in which later a banded $\mathrm{Bt}$ horizon was formed.

A near vertical thin layer, consisting of silt-sludge with oriented mica's, results from activity event F1. It shows in-situ clay coatings surrounding the layer and a few in pores within the layer (Fig. 3). This also points to clay illuviation postdating fault activity event F1.

F2: Fig. 4 presents an overall view of sample sma 5: clearly visible is the distinction between the lighter coloured top part, the abrupt boundary to the underlying reddish brown part, interrupted in the center by the mouth of the lighter coloured infilled fissure and two, more narrow, planar openings breaking through the reddish brown band as well. Optical observations of the reddish brown material demonstrated the presence of many in-situ translucent, orange-yellow, strongly oriented, fine textured coatings forming a bridged grain microstructure (Fig. 2).

In the light coloured toppart of the sample a clear stratification is absent. It contains small (100 $\mu \mathrm{m}-$ several $\mathrm{mm}$ in size) fragments of banded Bt material and fragmented clay coatings. Occasionally in situ clay coatings occur. Part of the coatings demonstrate a slightly to strongly grainy appearrance. The fissure does not extend into the colluvium: it has broken the already existing Bt band. We interpret this layer as Late Weichselian colluvium which contains fragments from earlier formed banded Bt horizons and which has experienced still some clay illuviation after its deposition. Watermovement and occasional water saturation is responsible for the grainy character of some 

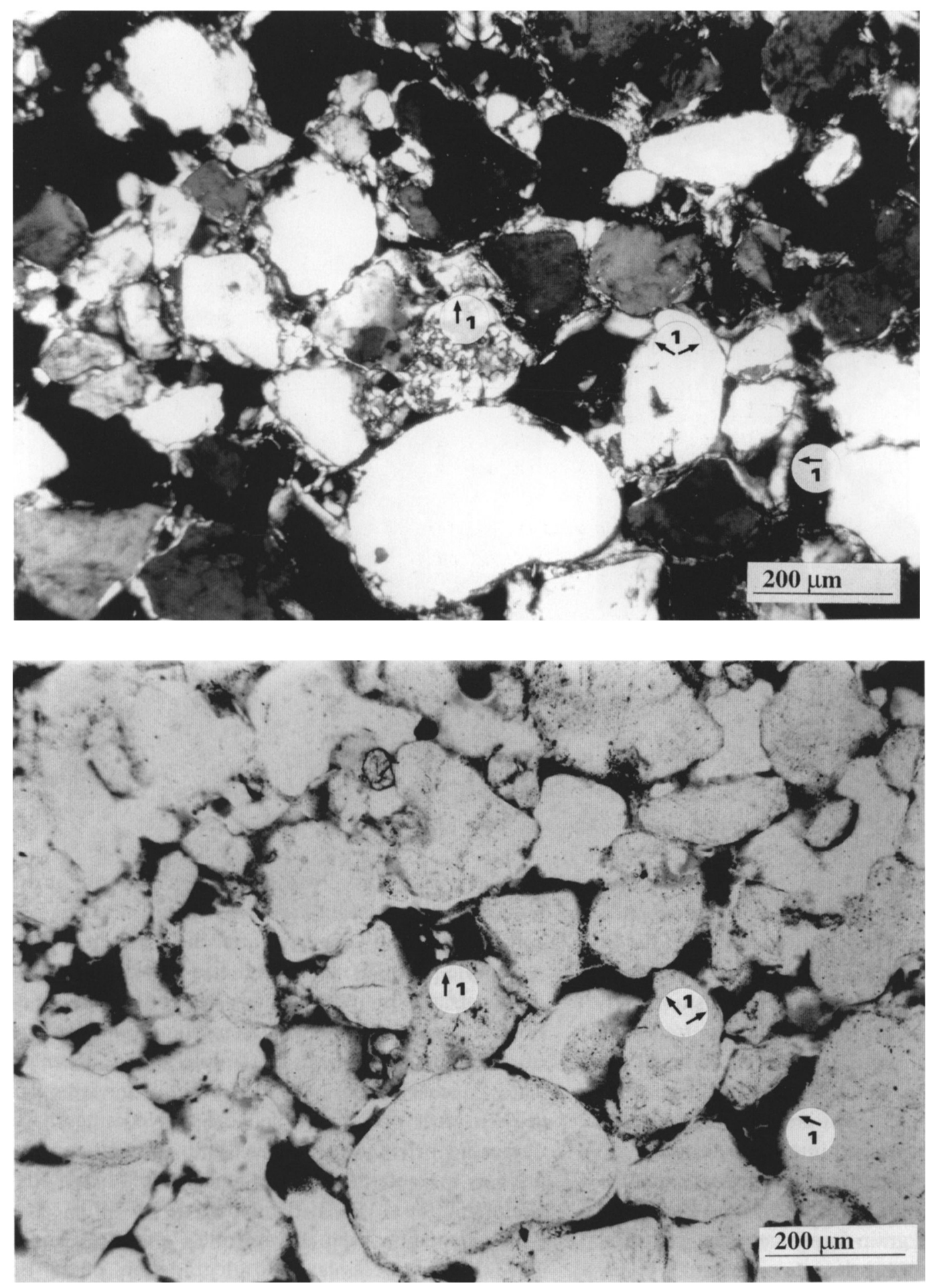

Fig. 2. Bridged grain microstructure (free grain - 1 - and vugh clay coatings) in the banded Bt horizons (XPL and PPL).

coatings (ferrolysis: Brinkman et al. 1973; Brinkman, 1979 - Fig. 5).

Pine trees in the Allerød and Preboreal favour important snow melt (Van Vliet-Lanoë, 1993) adding to such degradation features.

The infilling of the fissure is characterised by random distributed sand grains with occasional small (100-500 $\mu \mathrm{m})$ rounded fragmented clay coatings originating from the overlying colluvium. In situ clay coatings are absent. The fissure acts as a preferential drainage site and has been passively infilled by colluvial material, with occasional organic matter containing soil aggregates in the lower part of the infilling.

Focusing on the sequence of events in this sample, micromorphological observations demonstrate that in the in-situ fluvial-aeolian deposit a banded Bt horizon was formed as a result of pedogenesis. This horizon is cracked by the F2 event of the PBF, resulting in for- 

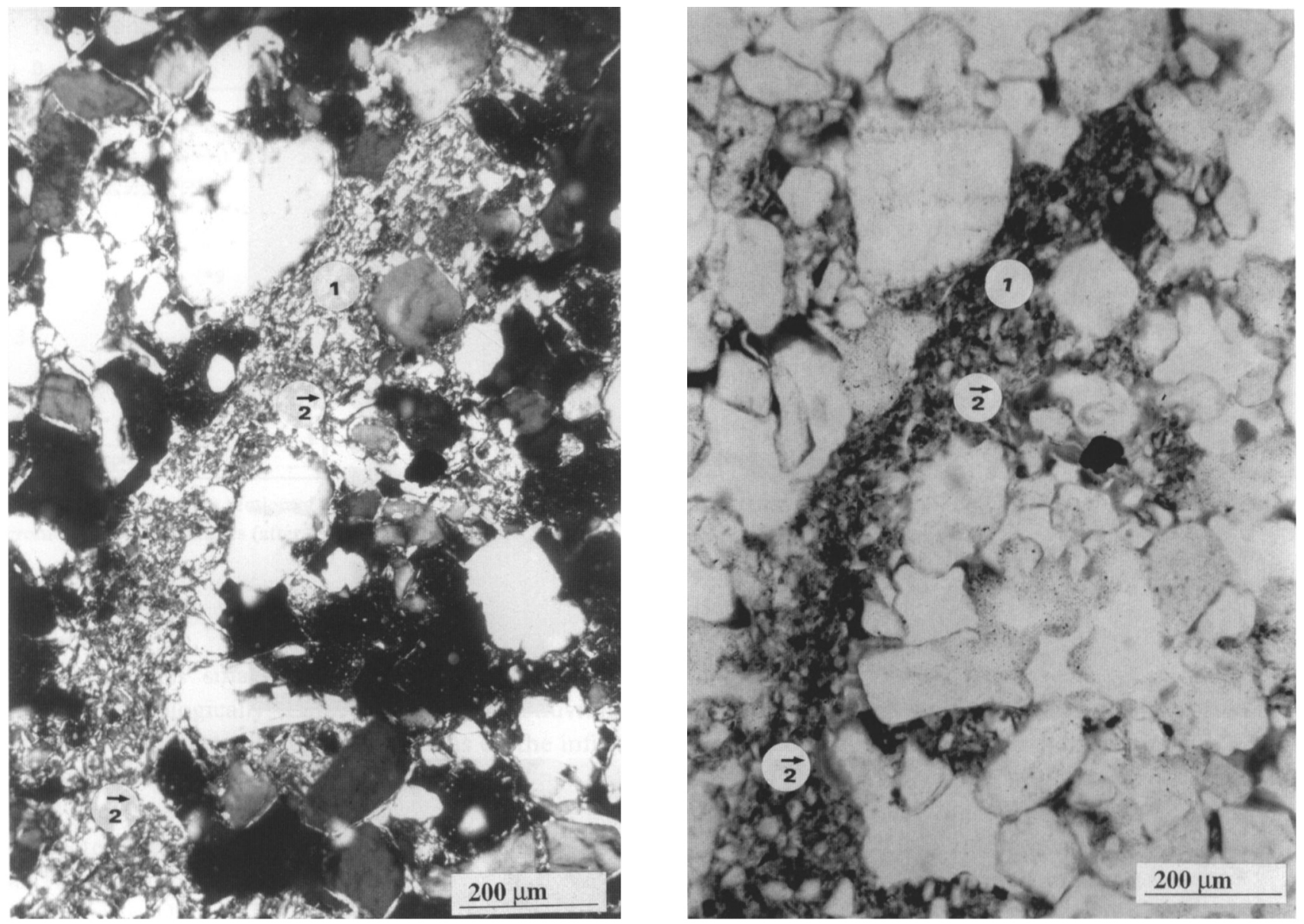

Fig. 3. In-situ clay coatings - 2- surrounding the vertically oriented silt-sludge layer with oriented mica's - 1 - (XPL and PPL).

mation of fissures. These fussures do not continue into the overlying deposit, so after the F2 event Late Weichselian colluvium was deposited on top of the Bt horizon and in the fissures. Some clay translocation has taken place in this colluvium after deposition.

F2: In sample sma 1 we can clearly trace the boundary between the Late Weichselian colluvial deposits and the in-situ fluvial-aeolian deposits. The sample contains a infilled fault crack, that breaks the $\mathrm{Bt}$ band, but does not extend into the overlying Late Weichselian colluvium (identical with sample sma 5 Fig. 4). The infilling consists of well sorted finer sand with some in-situ free grain translucent clay coatings, but considerably less than the surrounding $\mathrm{Bt}$ band. At the boundary between the infilled fault and the in situ Bt band a tilted zone occurs, consisting of striated fine textured, displaced rounded fragments of $\mathrm{Bt}$ bands in which rotation features are observed (circular distribution pattern of the sand grains - Fig. 6).

We interpret this phenomenon as mechanical displacement of water saturated $\mathrm{Bt}$ material during the fault activity event F2. These features are the result from active faulting (Van Vliet-Lanoë, 1988, 1993). Surrounding these rotational fragments, in-situ clay illuviation features are observed. We conclude that the major Bt band was already present at the time of the fault activity event $F 2$, but subsequent, less intense, clay illuviation still occurred after the F2 event.

Sample sma 3 is taken in the in-situ deposits and demonstrates many translucent, strongly oriented, fine textured clay coatings illustrating the occurrence of a banded Bt horizon. In sample sma 2, taken in Late Weichselian colluvial deposits, large irregular greyish areas occur in which the clay coatings have decreased orientation patterns and a grainy appearance as a result of the pedogenic proces 'ferrolysis' (Brinkman et al. 1973; Brinkman, 1979 - Fig. 5) in which also snow melt plays a role (Van Vliet-Lanoë, 1993). This process leads to 'degradation' of the Bt horizon of Luvisols, transforming them into Podzoluvisols (Targulian et al, 1974; Miedema, 1987; Miedema et al, 1999). Such grainy coatings also occur on the top part of the $\mathrm{Bt}$ bands and around the outer edges of large fragments of the Bt horizon in the colluvium in the top of sample sma 1. Along these zones of preferential watermovement also $\mathrm{Fe} / \mathrm{Mn}$ covering of clay coatings is observed more frequently. In the top part of sample sma 2 large (several $\mathrm{cm}$ ) fragments of $\mathrm{Bt}$ material occur, pointing to mechanical transport of these $\mathrm{Bt}$ fragments with the deposition of the 


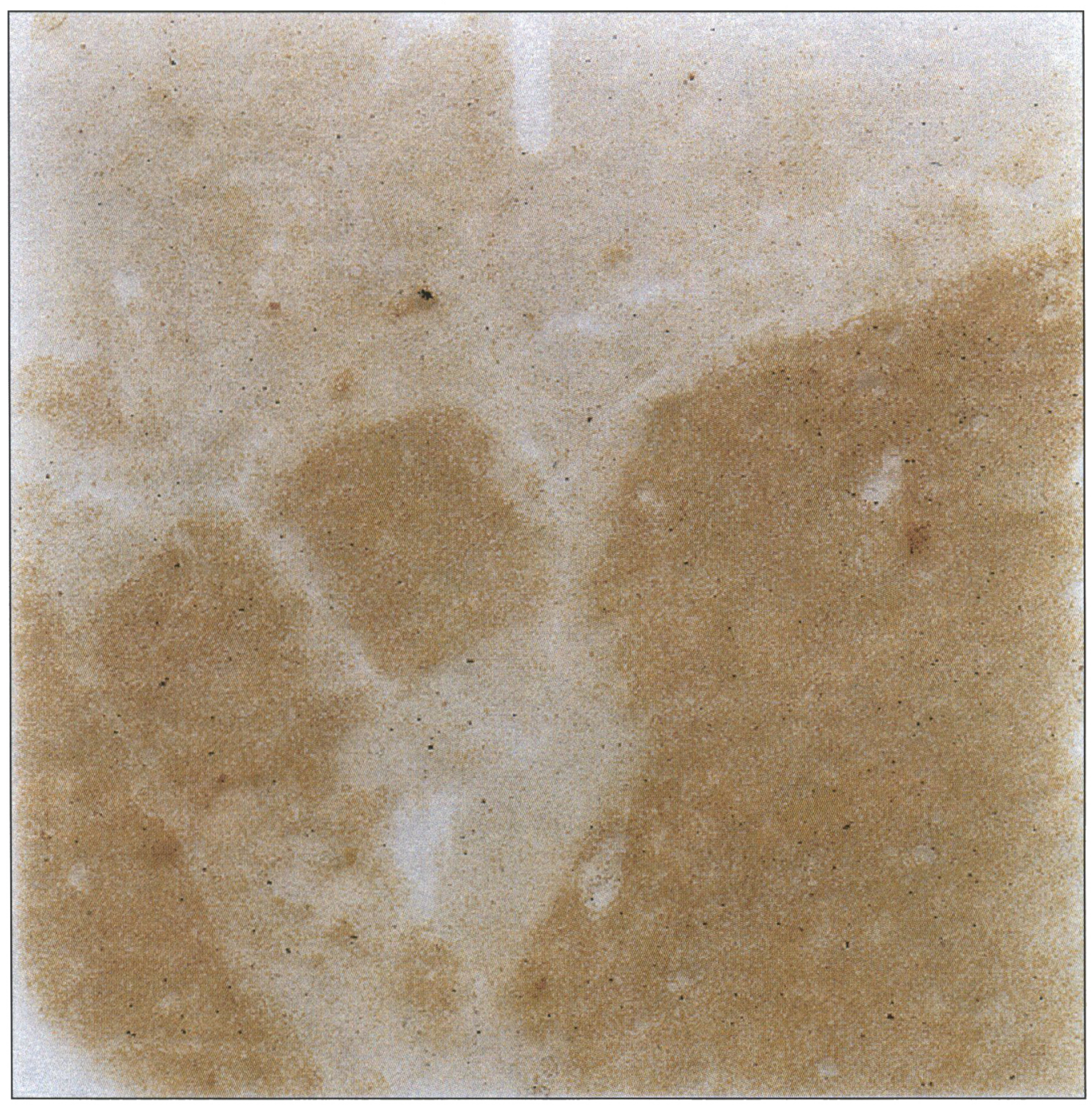

Fig. 4. Sample sma 5 with Late Weichselian colluvium overlying in-situ banded $\mathrm{Bt}$ horizon with infilled fissures (PPL). The real width of the sample is $7 \mathrm{~cm}$.

Late Weichselian colluvium. The bottom part of this sample shows a $\mathrm{Bt}$ with an irregular angular shape. This can be interpreted as a still larger fragment of the Bt mechanically included in the Late Weichselian colluvium. Then the banded Bt horizons indicated in the colluvial part of the geological cross section in fact consist of colluvial fragments of earlier formed $\mathrm{Bt}$ horizons. Alternatively the bottom Bt part of sma 2 is formed in-situ in the Late Weichselian colluvium and its angular shape is the result of the degradation process (ferrolysis), described above. Depending on the interpretation chosen, we either have 1 layer of Late Weichselian colluvium with included small or large lumps of $\mathrm{Bt}$ material or we have at least two main phases of $\mathrm{Bt}$ formation (the oldest in the insitu Late Weichselian deposits; the younger in the Late Weichselian colluvia). We find mechanically transported fragments of the older Bt horizons in the oldest colluvium and of the younger Bt horizon in the youngest colluvium. We favour this latter hypothesis of at least two main phases of clay illuviation: Miedema et al. (1983) demonstrated clay illu- viation in all Late Weichselian terrace levels of Tebbens et al. (1999).

F3: Samples sma $4 \mathrm{a} / 4 \mathrm{~b}$ are a vertical and a horizontal section across an organic matter containing fault in the Late Weichselian colluvium. The colluvial nature of the deposit is manifest by the frequent occurrence of large $(0.5-2 \mathrm{~cm})$ subrounded fragments of $\mathrm{Bt}$ bands scattered throughout the sample. The organic matter rich fault forms a part of a larger fault zone within the sample, in which no in-situ clay illuviation features are observed. Fault activity evidence is the tilting of surrounding $\mathrm{Bt}$ bands and associated fissuring, the offset along the fault zone of the Bt band and the well sorted mix of mechanically transported fragments of $\mathrm{Bt}$ bands in the larger fault zone. The organic matter is well aggregated moder humus, formed by biological activity after decay of a recent Holocene root that has extended into a fissure in the centre of the larger fault zone within the sample. With depth organic matter content decreases. The larger fault zone is more recent than the $\mathrm{Bt}$ formation, because of its mechanical infilling with well sorted Bt frag- 
ments. We hypothesize that the larger fault zone in the samples sma $4 \mathrm{a} / \mathrm{b}$ is associated with the $\mathrm{F} 2$ event.

\section{Additional samples without clear reference to F1-F3:}

In sample sma 7 we observe a large infilled fault with well sorted, non stratified grey-white sand without insitu clay illuviation. The infilled fault occurs between tilted $\mathrm{Bt}$ bands with in-situ free grain clay coatings as descibed above, occurring in alternating coarse fine gravelly sand and fine sand. The absence in the infilling of in-situ clay coatings indicates that the infilled fault is younger than the banded Bt surrounding it. The thin band in the top part of the infilling has formed from micro-eroded banded Bts fragments from the sides, as a consequence of fault activity.
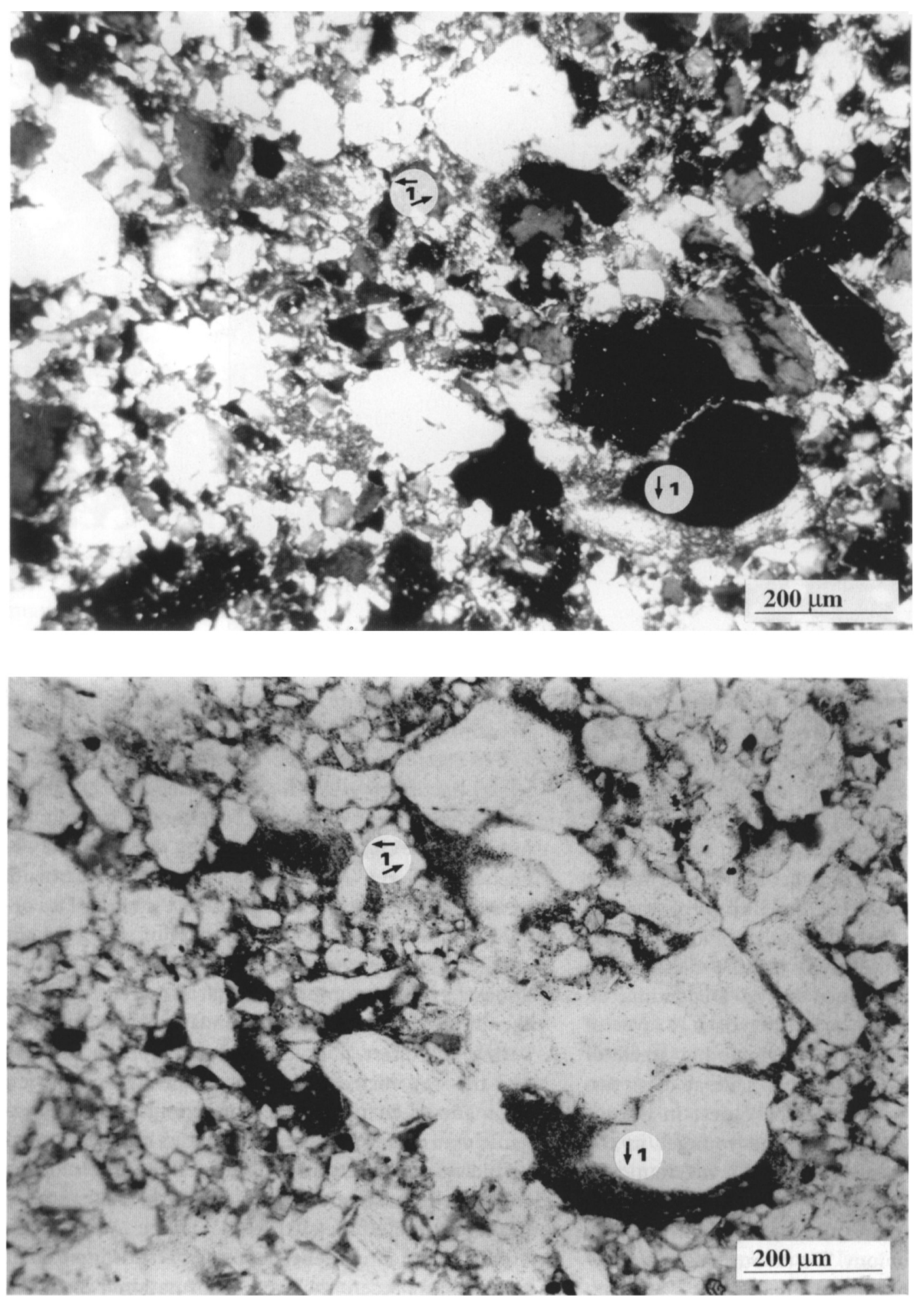

Fig. 5. Ferrolysis affecting clay illuviation coatings (grainy coatings - 1) (XPL/PPL). 

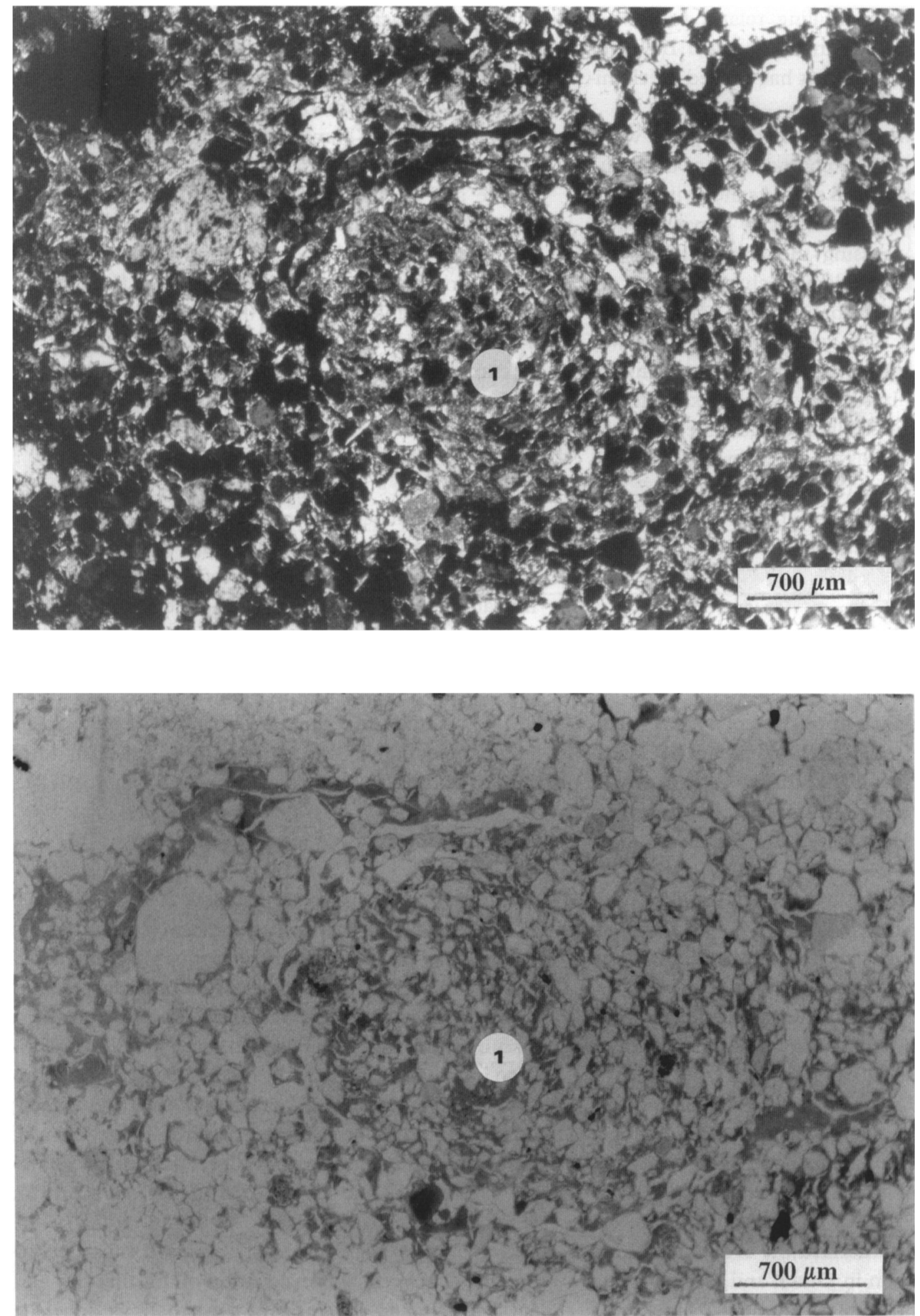

Fig. 6. Rotation feature (circular distribution pattern of the sand grains - 1) in sma 1, caused by 'mudflow' during active faulting during the F2 event.

Sample sma 8 is taken at the crossing of two sets of grey-white infillings. These infillings are dominated by loosely packed, well sorted grey-white sand without in-situ clay illuviation. Alongside the grey-white infilling oblique to nearly vertical thin bands with rounded fragments of Bt material occur, with com- monly clay coatings with $\mathrm{Fe} / \mathrm{Mn}$. These are testimony of mechanical transport and preferential water movement alongside the fault edges. This 'mudflow' results from active faulting (Van Vliet-Lanoë, 1988, 1993). The infilling does not relate to the $F 1$ event, because otherwise in-situ clay illuviation should occur in the 
infilling. Most likely the infilling relates to the F2 event, when clay illuviation in the form of $\mathrm{Bt}$ bands already occurs and the $\mathrm{F} 2$ event has caused mechanical displacement of the $\mathrm{Bt}$ band.

Sample sma 9 is in a zone where frequent white coloured fissures occur. The composition of the white infilling is homogeneous well sorted sand, without organic matter and without in-situ clay illuviation features. The Bt band crossing the grey-white fissure shows all the micromorphological characteristics described above for similar banded $\mathrm{Bt}$ horizons and postdates the infilling. The interpretation of the way of formation of this grey-white infilling remains inconclusive, although its origin as a relaxationcrack seems more likely. The infilling could date from the F1 event, because it is crossed by an in-situ Bt band, but it could also relate to the F2 event, because clay illuviation still occurs later than the F2 event (Fig. 7: Van den Berg and Lokhorst, 1999).

\section{Discussion and synthesis}

Van den Berg and Lokhorst (1999) illustrated the presence of the Beuningen gravel bed of approximately 16000 years B.P as well as the occurrence of (banded) $\mathrm{Bt}$ horizons and associated dung beetle burrows. The offset of the the Beuningen gravel bed shows two steps ( $F 1$ and $F 2$ ). Both $F 1$ and $F 2$ thus postdate 16000 years B.P.

Brussaard and Runia (1984) reported evidence of simultaneous scarab dung beetle activity and banded $\mathrm{Bt}$ horizon formation during the interstadials of the Late Weichselian period and during the Early Preboreal in Late Weichselian Meuse deposits near Geysteren. This corroborates the conclusions drawn by Van Vliet-Lanoë (1985, 1988).Van Vliet-Lanoë (1990) summarizes Late Weichselian Bt horizon formation in Weichselian loess in northwestern Europe, based on earlier papers (e.g. Langohr and Van Vliet, 1979; Van Vliet-Lanoë and Langohr, 1981; Langohr and Pajares, 1983).

Miedema (1992) summarized the evidence of Late Weichselian Bt formation in Dutch and German Late Weichselian Rhine and Meuse sediments (Hoeksema and Edelman, 1960; De Bakker, 1965; Miedema et al., 1978; Schröder, 1979; Miedema et al., 1983; Jongmans and Miedema, 1986; Miedema, 1987).

However, other authors (e.g. Jamagne, 1969; Fedoroff, 1972; Hoffman and Blume, 1977; McKeague, 1983; Mücher, 1986, Kemp, 1999; Miedema et al. 1999) advocated an exclusively Holocene formation or Holocene phases of Bt horizon formation. Van Vliet-Lanoë (1988) stressed that the occurrence of clay illuviation depends on decalcification period and local climatic conditions. Evidence for our hypothesis of Late Weichselian formation of the $\mathrm{Bt}$ horizon in the studied Meuse sediments, is based on:

The rapid and complete Late Glacial decalcification in the Late Weichselian fluvial sediments of Rhine and Meuse (Jongmans and Miedema, 1986) and Late Weichselian coversand (Buurman,1970).

The presence of fragic properties in the $\mathrm{Bt}$ horizon which originate from periglacial cycles of freezing and thawing (Sevink et al., 1970; Langohr and Pajares, 1983; Van Vliet-Lanoë, 1990). Miedema (1987,1992) documented such fragic properties in the Bt horizon in Late Weichselian Rhine deposits, and the authors observed such phenomena also in Bt horizons in Late Weichselian Meuse deposits.

The presence of a $\mathrm{Bt}$ horizon below Late Weichselian and Holocene deposits of the Rhine and the Meuse (De Bakker, 1965; Miedema, 1992).

The absence of clay illuviation features in Holocene fluvial deposits of varying age of the Rhine and the Meuse in the Netherlands (Miedema, 1987). Also Schröder (1979) reported absence of clay illuviation in German Rhine deposits younger than Preboreal.

The occurrence of high proportions of biologically fragmented clay coatings in Late Weichselian loess soils in South Limburg (Miedema and Slager, 1972).

\section{Podzolisation processes}

Van Mourik (personal communication, 2000) found 5500 $\mathrm{BP}$ as oldest date on the organic matter and sequioxides from podzolisation processes. Clay illuviation is possible in a $\mathrm{pH}$ range from $6.5-5.0$. When the $\mathrm{pH}$ drops further, the clay particles are stabilised by aluminium. Then podzolisation takes over. This means that (long) before 5500 BP clay illuviation must have stopped. At the onset and outgoing of an interstadial/ interglacial period frequent freezing and thawing cycles and seasonal deep frost are maximal. The rewetting of the soil at the onset of thawing produces the high ratio of water to dispersed fine clay needed (Sehgal et al., 1976; Gombeer and d'Hoore, 1971).

It promotes aggregate destabilisation thus liberating fine clay. Vertical translocation of this fine clay and accumulation in the form of clay coatings once the underlying frozen layer also thawes causes the development of a Bt horizon. Schematically the Bt soil formation intensity is illustrated in Fig. 7 (Van den Berg and Lokhorst, 1999). The synthesis of the micromorphology of the Neer trench related to Fig. 7 shows that the F1 activity event of the Peel Boundary Fault postdates the Beuningen gravel but presumably predates the Bølling interstadial. The sedimentary bedding has been offset in two steps and during the fault 


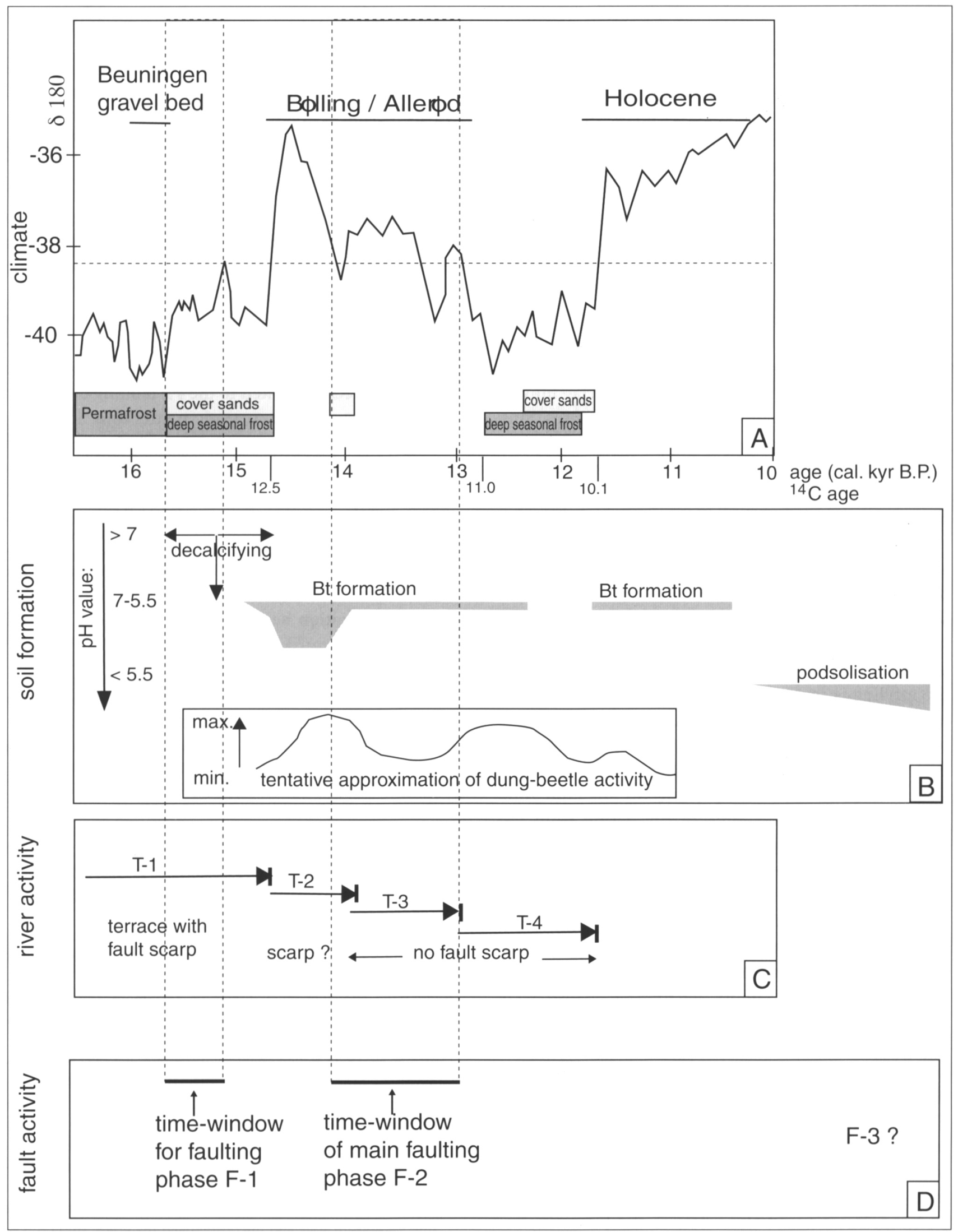

Fig. 7. PBF activity events in time, related to river activity, soil formation and climate (source:Van den Berg and Lokhorst, 1999).

activity event $\mathrm{F} 1$ also the near vertical silt-sludge layer was formed (sma 6). At the beginning and end of the Bølling and the Allerød clay illuvation can have taken place. In-situ clay illuviation is found around the near vertical silt-sludge layer of the F1 event and sma 1 and sma 5 demonstrate that the banded $\mathrm{Bt}$ horizon 
was already formed before the F2 event (Bølling/ Allerød). The faults are younger than the banded $\mathrm{Bt}$, but older than the overlying (two?) Late Weichselian colluvia, because they do not extend into the colluvia (Old Dryas/Allerød and Young Dryas/Preboreal?). The infilling of the faults originates from the overlying colluvium (no stratification), shows fragmented clay coatings derived from the earlier formed $\mathrm{Bt}$ and some in-situ coatings occur in the colluvia along zones of preferential water movement. Along these zones also degradation (ferrolysis) and $\mathrm{Fe} / \mathrm{Mn}$ covering of clay coatings is found.

The tilted layer with mechanically displaced water saturated Bt material, showing rotational features in sma 1, resulted from the fault activity F2. Within this tilted layer also some more recent in-situ clay illuviation is found surrounding the rotational features. Sma 2 and sma 3 detail the features of the $\mathrm{Bt}$ and its rather complex Holocene ongoing degradation (ferrolysis Brinkman 1970; Brinkman et al.,1973) in the upper part. Sma $4 a / 4 b(F 3)$ is located in the youngest colluvium. This colluvium only shows frequent subrounded fragments and tilted fragments of Bt bands, evidencing its age younger than Bølling/Allerød, presumably Young Dryas/Preboreal as it contains no insitu clay coatings. The inner, organic part of the fault does not show clay illuviation features, so this part of the infilling is recent (Holocene). A root has used an existing fissure, has died, and the organic material is turned into moder by biological activity. In the outer part of the larger fault zone within sample sma $4 \mathrm{a} / \mathrm{b}$ fragments of $\mathrm{Bt}$ bands are present. So this fault zone is post-Bølling/Allerød, presumably dating from the F2 event, with a (much) more recent reopened interior, organic matter containing part.

The fault crack in sma 8 is accompanied by oblique to near vertical mechanically transported fragments of Bt (Bølling/Allerød) zones. The infilling does not relate to the $\mathrm{F} 1$ event, because otherwise in situ clay illuviation should occur in the infilling. Most likely the infilling relates to the $\mathrm{F} 2$ event, when clay illuviation in the form of Bt bands already occurs and the active faulting F2 event has caused mechanical displacement of the Bt band.

Sma 9 shows an Bølling/Allerød Bt band, crossing a white relaxation(?) fissure. The well sorted infilling without sedimentary bedding structures could date from the F1 event, because it is crossed by an in-situ $\mathrm{Bt}$ band, but it could also relate to the F2 event, because in-situ clay illuviation still occurs later than the F2 event (Fig. 7: Van den Berg en Lokhorst, 1999).

\section{Conclusions}

The micromorphological interpretation of Late Weichselian soil formation agrees with the hypothesized $3 \mathrm{PBF}$ periods of fault activity events:

Between Beuningen and the onset of the Bølling (F1)

Between/within Bølling/Allerød and Young Dryas/ Preboreal (F2 event). The larger fault disturbance part F3 presumably belongs to $\mathrm{F} 2$ event, or forms a separate event as it occurs in the presumed Young Dryas/Preboreal colluvial material.

The rotation features (Fig. 6) oberved in sma 1 , sma $4 \mathrm{a} / \mathrm{b}$ and sma 8 , caused by mechanical 'mudflow' displacement are clear and convincing evidence of active faulting (especially related to the F2 faulting event).

The fault trace with organic matter and no clay illuviation features, presumed to be a fault trace from a young to middle Holocene PBF event (F3) presumably is just from the decay of a Holocene root, occupying a fissure in the center of the fault trace, mentioned under 2 .

The mode of formation of the white fissures to the north of the F1 offset remains unclear, although the time of formation seems to relate to the F1 or F2 event.

\section{References}

Brinkman, R. 1970. Ferrolysis, a hydromorphic soil forming process. Geoderma 3, 199-206.

Brinkman, R. A.G. Jongmans, R. Miedema and P. Maaskant 1973. Clay decomposition in seasonally wet, acid soils: micromorphological, chemical and mineralogical evidence from individual argillans. Geoderma 10: 259-270.

Brinkman, R. 1979. Ferrolysis, a soil forming process in hydromorphic conditions. PhD thesis, Wageningen. Agr. Res. Rept. 887: $106 \mathrm{pp}$.

Brussaard, L. and L.T. Runia 1984. Recent and ancient traces of scarab beetle activity in sandy soils of the Netherlands. Geoderma 34: 229-250.

Bullock, P., N. Fedoroff, A. Jongerius, G. Stoops and T. Tursina 1985. Handbook for soil thin section description. Waine Research Publications, Wolverhampton, U.K., 152 pp.

Buurman, P. 1970. Pollen analyses of the Helvoirt river valley. Geologie en Mijnbouw 49: 381-390De Bakker, H. 1965. Tonverlagerung in Fluszablagerungen verschiedener Art. Mitt Deutsche Bodenk. Gesellschaft 4: 123-128.

Fedoroff, N. 1972. Micromorphological characteristics of Quaternary pedogenesis in France. In: M. Ters: Studies of the Quaternary throughout the world 1:341-349.

Fitzpatrick, E.A. 1970. A technique for the preparation of large thin sections of soils and unconsolidated materials. In: D.A. Osmond and P. Bullock (Eds): Micromorphological techniques and applications. Techn. Monograph 2: 3-13.

Gombeer, R. and J. d'Hoore 1971. Induced migration of clay and other moderately mobile constituents. III Critical soil/water dispersion ratio, colloid stability and electrophoretic mobility. Pédologie 21:311-342. 
Hoeksema. K.J. and C.H. Edelman 1960. The role of biological homogenization in the formation and transformation of gray brown podzolic soils. Transactions 7 th Int. Congr. Soil Sci., Madison, U.S.A. 4: 402-405.

Hoffman, R. and H.P. Blume 1977. Holocene clay migration as a soil forming process in loamy soils of the moraine landscapes of north Germany. Catena 4: 359-368.

Jamagne, M. 1969. Sols et paléosols sur loess dans le nord de la France. Etude du Quaternaire dans le monde. VIII Congrès INQUA, Vol. I, 359-372.

Jongmans, A.G. and R. Miedema 1986. Morphology, genesis and distribution of calacareous material in Late Weichselian sediments of the Rhine and Meuse rivers in the eastern part of the Netherlands. Neth. J. agric. Sci. 34: 441-449.

Kasse, C., J. Vandenberghe and S.J.P. Bohncke 1995. Climatic change and fluvial dynamics of the Maas during the Late Weichselian and Early Holocene. In: B. Frenzel, J. Vandenberghe, C. Kasse, S.J.P. Bohncke and B. Gläser (Eds): European river activity and climatic change during the Late Glacial and Early Holocene.

Kemp, R.A. 1999. Micromorphology of loess-paleosol sequences: a record pf paleoenvironmental change. Catena 35: 179-196.

Langohr, R. and G. Pajares 1983. The chrono-sequence of pedogenic processes in Fraglossudalfs of the Belgian loess belt. In: P. Bullock and C.P. Murphy (Eds): Soil Micromorphology, 2: 503510. AB Academic Publishers, Berkhamsted, U.K.

Langohr, R. and B. van Vliet 1979. Clay migration in well to moderately well drained acid brown soils of the Belgian Ardennes. Morphology and clay content determination. Pédologie 29: $367-$ 385 .

McKeague, J.A. 1983. Clay skins and argillic horizons. In: P. Bullock and C.P. Murphy (Eds): Soil Micromorphology, Vol I, $367-$ 388. AB Academic Publishers, Berkhamsted, U.K.

Miedema, R. 1987. Soil formation, microstructure and physical behaviour of Late Weichselian and Holocene Rhine deposits in the Netherlands. PhD thesis Wageningen Agricultural University, The Netherlands, $339 \mathrm{pp}$.

Miedema, R. 1992. Processus de formation des sols tardiglaciaires et holocènes sur les terrasses alluviales du Rhin aux Pays-Bas. Science du Sol 30: 149-168

Micdema, R. and S. Slager 1972. Micromorphological quantification of clay illuviation. J. Soil Sci. 23: 309-315.

Miedema, R. E. van Engelen and Th. Pape 1978. Micromorphology of a toposequence of Late Pleistocene fluviatile soils in the eastern part of the Netherlands. In: M. Delgado(Ed): Micromofologia de Suelos, 1: 469-501. T. Arte Prieto Moreno, Maracena (Granada), Spain.

Miedema, R., S. Slager, A.G. Jongmans and Th. Pape 1983. Amount, characteristics and significance of clay illuviation features in Late Weichselian Meuse terraces. In: P. Bullock and C.P. Murphy (Eds): Soil Micromorphology, 2: 519-531. AB Academic Publishers, Berkhamsted, U.K.
Miedema, R., I.N. Kulechova and M.I. Gerasimova 1999. Soil formation in Greyzems in Moscow district: micromorphology, chemistry, clay mineralogy and particle size distribution. Catena 34: 315-347.

Mücher, H.J. 1986. Aspects of loess and loess-derived slope deposits: an experimental and micromorphological approach. PhD thesis University of Amsterdam. Nederl. Geogr. Studies 23: 267 pp.

Schröder, D. 1979. Bodenentwicklung in spätpleistozänen und holozänen Hochflutlehemen des Niederrheines. Habilitationsschrift Bonn, 296 pp.

Seghal, J.L., R. Gombeer and J. d'Hoore 1976. Clay migration in the formation of the argillic horizon in soils developed under varying moisture regimes. J. Indian Soc. Soil Sci. 24: 20-28.

Sevink, J., O. Hulshof, H.J. Mücher and S.B. Kroonenberg 1970. Age and development of some fossil podzols in the Dinkel Valley (E. Netherlands).

Physical Geographical and Soil Laboratory: from field to laboratory publication 16 .

Targulian, V.O., A.G. Birina, A.V. Kulikov, T.A. Sokolova and L.K. Tselischcheva 1974. Arrangement, composition and genesis of sod-pale-podzolic soil derived from mantle loams. Morphological investigation (47pp) and analytical investigation Int. Congr. Soil Sci. Moscow: 107 pp.

Tebbens,L.A., A. Veldkamp, W. Westerhoff and S.B. Kroonenberg 1999. Fluvial incision and channel downcutting as a response to Late-glacial and Early Holocene climate change: the lower reach of the river Meuse (Maas), The Netherlands. J. Quatern. Sci. 14: 59-75.

Van den Berg, M.W. 1996. Fluvial sequences of the Maas. A $10 \mathrm{Ma}$ record of neotectonics and climate change at various time scales. $\mathrm{PhD}$ thesis Wageningen Agricultural University, The Netherlands: $181 \mathrm{pp}$.

Van den Berg, M.W. and A. Lokhorst 1999. Paleoseismic investigations along the Peel boundary fault: geological setting, site selection and trenching results. In: T. Camelbeeck (Ed): Contributions to the workshop on evaluation of the potential for large earthquakes in present day low seismic activity regions of Europe. Han sur Less, Belgium: 4 pp.

Van Vliet-Lanoe, B. 1985. Frost effects in soils. In: J. Boardman (Ed): Soils and Quaternary Landscape Evolution. John Wiley and Sons Ltd, (Chichester, U.K.): 117-158.

Van Vliet-Lanoë, B. 1988. Le rôle de la glace de ségrégation dans les formations superficielle de l'Europe de l'ouest. Thèse de Doctorat d'Etat, Sorbonne: 854 pp.

Van Vliet-Lanoë, B. 1990. The genesis and age of the argillic horizon in Weichselian loess in northwestern Europe. Quaternary International 5: 49-56.

Van Vliet-Lanoë, B. and R. Langohr 1981. Correlation between fragipans and permafrost with special reference to silty Weichselian deposits in Belgium and northern France. Catena 8: 137154. 